\title{
POSITION AND MANAGEMENT STRATEGY FOR PUBLIC GREEN OPEN SPACES IN THE CITY OF DENPASAR, BALI PROVINCE
}

\author{
Mei Indrawati ${ }^{1}$ (1) , Aa K Sudiana ${ }^{2}$ and K Sumantra ${ }^{3}$ \\ ${ }^{1}$ Masters Program in Regional Planning and Environmental Management, Mahasaraswati University of Denpasar, Bali, \\ Indonesia \\ ${ }^{2}$ Faculty of Law, Mahasaraswati University Denpasar, Bali, Indonesia \\ ${ }^{3}$ Faculty of Agriculture, Mahasaraswati University of Denpasar, Bali, Indonesia
}
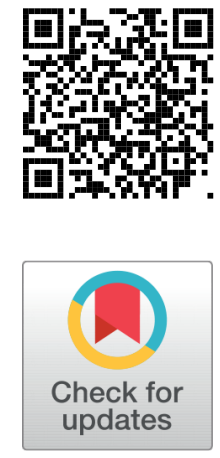

Received 25 June 2021

Accepted 9 July 2021

Published 31 July 2021

Corresponding Author

Mei Indrawati, meiwirandana219

6@gmail.com

DOI $10.29121 /$

granthaalayah.v9.i7.2021.4082

Funding: This research received no specific grant from any funding agency in the public, commercial, or not-for-profit sectors.

Copyright: (C) 2021 The Author(s). This is an open access article distributed under the terms of the Creative Commons Attribution License, which permits unrestricted use, distribution, and reproduction in any medium, provided the original author and source are credited.

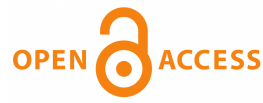

\section{ABSTRACT}

Green Open Space "RTH" plays a very important role in realizing a sustainable city and has a balance of functions both ecologically and psychologically for urban communities. Green Open Space can be divided into two, namely public green open space and private green open space, but only public green open space can still be controlled directly by the government. The purpose of this study is to identify the availability of public green open space in the city of Denpasar and to formulate strategies and policies for managing public green open space in the city of Denpasar. Data collection techniques were carried out using interviews and questionnaires, qualitative and quantitative descriptive data analysis with SWOT analysis for the use of public green open space, and the Analytical Hierarchy Process (AHP) to determine management strategies and policies. The availability of public green open space in 2011 was recorded at 2,341.48 or 18.32 percent. The availability of public green open space in 2019 was recorded at 1,572,990 ha or 12.49 percent. The difference in 2011 and 2019 was 768,490 Ha or 5.83 percent. The minimum area for public green open space following the 20 percent rule is 1.68 percent (in 2011) and 7.51 percent (in 2019). The implementation of Denpasar Public Green Open Space (RTH) management has not met the standards of the Minister of Home Affairs Regulation Number 1 of 2007 and Minister of Public Works Number 5 of 2008. The strategy for managing Green Open Space is to develop detailed spatial plans, install information boards, enforce laws, and implement incentives disincentives to relevant stakeholders

Keywords: Green Open Space, Public, Management Strategy

\section{INTRODUCTION}

Government Regulation Number 26 of 2008 concerning the National Spatial Planning (RTRWN) which is further accommodated in the Regional Regulation of the 
Province of Bali Number 26 of 2009 concerning the Spatial Planning of the Province of Bali (RTRWP) of Bali in 2009-2029, confirms that Denpasar City is integrated into the Region The Denpasar-Badung-Gianyar-Tabanan (Sarbagita) city in the national urban system is designated as the National Activity Center (PKN) and subsequently the Sarbagita City has also been designated as the National Strategic Area (KSN). The area of the Sarbagita area is $723.99 \mathrm{~km}^{2}$ or $41.37 \%$ of the total area of the four regencies/cities in the Sarbagita area or $12.85 \%$ of the total area of Bali Province. The total area of Public and Private Green Open Space (RTH) spread across the Sarbagita Area in 2015 in Denpasar City was 4,214.70 Ha or 22.41\%.

The development of the population in urban areas accompanied by an increase in the flow of urbanization brought major changes to basic human needs, namely the need for boards and their supporting facilities (Alfiah (2008) ). The development of the population which brings consequences to developments in all areas of life requires spatial arrangements so that the utilization and use of space can be carried out optimally based on cultural values (Reklaitiene et al. (2014) ; As-Syakur (2011) ). Space cannot be separated from humans either psychologically, emotionally, or dimensionally. The use of urban land that continues to increase and is accelerating for the construction of various urban facilities, urban facilities, and infrastructure, including advances in industrial and transportation technology, in addition to frequently changing the natural functions of land/urban landscapes, also confiscates these lands and various other open spaces (Bettinger et al. (2009); Chili (2004 a, 2004 b, 2004 c); CHILI (2005) ). Both of these things are very detrimental to the existence of green open space (RTH) which is often considered as reserve land and is not economical.

Green open space is an elongated area/lane and/or clustered, whose use is more open, where plants grow both naturally and intentionally (Permen PU No. 05/PRT/M/2008). In the Law of the Republic of Indonesia No. 26 of 2007 concerning Spatial Planning Article 29 paragraphs 1 and 2 states that the proportion of green open space in the city area is at least 30 percent of the city area, and the proportion of public green open space in the city area is at least 20 percent of the city area. The existence of green open space in urban areas has the aim of maintaining the harmony and balance of the urban environmental ecosystem, realizing a balance between the natural environment and the artificial environment in urban areas, and improving the quality of cities that are healthy, beautiful, clean and comfortable. As well as functioning as a safeguard for the existence of urban protected areas, controlling pollution and damage to soil, water, and air, protecting germplasm and biodiversity, controlling water management and as a means of urban aesthetics.

This research will focus on discussing the Public Green Open Space (RTH) because both ownership and the supply system are the property and authority of the government so that the government can optimally manage it. Related to this, it is necessary to identify the availability of green open space in Denpasar City, take an inventory of the existing green open space, and strategy for managing green open space in Den- 
pasar city.

\section{MATERIALS AND METHODS}

The study was conducted in the city of Denpasar from February to July 2020. The study used to interview and questionnaire methods. The type of data used is primary data, namely data directly obtained from the source and secondary data is data obtained from the Central Statistics Agency (BPS) City (2017) , and publications of several previous studies, journals, articles, books, and the internet. Qualitative and quantitative descriptive analysis techniques to determine the availability of public green open space (Sugiyono (2011) ), as well as SWOT analysis for the use of public green open space (Rangkuti (2000) ), and the Analytical Hierarchy Process (AHP) to determine management strategies and policies (David (2017) ).

\section{RESULTS AND DISCUSSION}

The results showed that the availability of public green open space (RTH) in 2011 was recorded at $2,341.48$ ha or 18.32 percent (Table 1 ). The details are presented in Table 1.

Table 1 Existing Public Green Open Space (RTH)of Denpasar city in 2011.

\begin{tabular}{llcc}
\hline No & Types of Public Green Open Space & \multicolumn{2}{c}{ Existing } \\
\hline 1 & & Area (Ha) & Percentage* (\%) \\
2 & Tahura Ngurah Rai & 588.99 & 4.61 \\
\hline 3 & Beach Border & 168.50 & 1.32 \\
\hline 4 & River Border & 208.53 & 1.63 \\
\hline 5 & Urban Forest RTHK & 45.08 & 0.35 \\
\hline 6 & Recreational and Sports Facilities & 246.12 & 1.93 \\
\hline 7 & Graves & 35,40 & 0.28 \\
& RTHK Agriculture (Ecotourism Rice & 781.76 & 6.12 \\
\hline 8 & Fields) & & 0.27 \\
\hline 9 & Government Offices & 34.01 & 0.06 \\
\hline 10 & Educational Facilities & 7.76 & 0.04 \\
\hline 11 & Medical facility & 4.98 & 0.08 \\
\hline 12 & Worship Facilities & 10.22 & 0.03 \\
\hline 13 & Dam Estuary & 3.30 & 1.57 \\
\hline 14 & Poad Network & 200.77 & 0.04 \\
\hline 15 & Terminal & 5.20 & 0.01 \\
\hline Total & & 0.87 & $\mathbf{1 8 . 3 2}$ \\
\hline
\end{tabular}

Source: RTRW Denpasar City 2011-2031

The availability of public green open space with data obtained from the Denpasar City Research and Development Agency in 2019 was recorded at 1,572,990 ha or 12.49 percent. The difference in data in 2011 and 2019 is 768,490 Ha or 5.83 percent. 
The minimum area for public green open space following the 20 percent rule is that 2011 data is 1.68 percent and 2019 data is 7.51 percent wide (Table 2 ).

Table 2 Existing Public Green Open Space (RTH) in 2019 in Denpasar City, Bali

\begin{tabular}{|c|c|c|c|c|c|c|c|c|}
\hline \multirow[t]{3}{*}{ No } & \multirow[t]{2}{*}{ Space Function } & \multicolumn{4}{|c|}{ District in Denpasar } & \multirow{2}{*}{$\begin{array}{l}\text { Den- } \\
\text { pasar } \\
\text { City }\end{array}$} & \multirow{2}{*}{$\begin{array}{l}\% \text { of } \\
\text { total } \\
\text { RTH }\end{array}$} & \multirow{2}{*}{$\begin{array}{c}\% \text { of } \\
\text { Den- } \\
\text { pasar } \\
\text { City } \\
\text { Area }\end{array}$} \\
\hline & & $\begin{array}{l}\text { West } \\
\text { Den- } \\
\text { pasar }\end{array}$ & $\begin{array}{l}\text { South } \\
\text { Den- } \\
\text { pasar }\end{array}$ & $\begin{array}{l}\text { East } \\
\text { Den- } \\
\text { pasar }\end{array}$ & $\begin{array}{l}\text { North } \\
\text { Den- } \\
\text { pasar }\end{array}$ & & & \\
\hline & \multicolumn{8}{|c|}{ Public Green Open Space (RTH) } \\
\hline 1 & Beach Border & 0.00 & 110.75 & 9.76 & 0.00 & 120.51 & 3.22 & 0.96 \\
\hline 2 & River Border & 4.54 & 5.11 & 6.29 & 5.35 & 21.28 & 0.57 & 0.17 \\
\hline 3 & Green Street & 4.09 & 16.61 & 4.91 & 2.95 & 28.55 & 0.76 & 0.23 \\
\hline 4 & City Park & 11.90 & 55.68 & 29.24 & 11.36 & 108.19 & 0.90 & 0.86 \\
\hline 5 & City Forest & 0.00 & 23.96 & 0.00 & 0.00 & 23.96 & 0.64 & 0.19 \\
\hline 6 & Graves & 11.17 & 8.39 & 3.79 & 1.62 & 24.97 & 0.67 & 0.20 \\
\hline 7 & LP2B & 20.30 & 369.12 & 459.16 & 396.95 & 1.245 .53 & 33.33 & 9.88 \\
\hline \multicolumn{2}{|c|}{ Sub Total RTH Public } & 52.00 & 589.62 & 513.15 & 418.23 & 1.572 .99 & 42.09 & 12.49 \\
\hline
\end{tabular}

Source: Bappeda R \& D Denpasar City, 2019

The Denpasar City Government has tried to include LP2B as part of the Public Green Open Space to fulfill a minimum area of 20 percent, and it is still lacking and efforts are still being made to include KDB and KLB to be included in the area of Denpasar City Public RTH to meet the target of at least 20 percent. Article 1 point 2 Permendagri No. 1 of 2007 concerning Urban Green Open Space defines urban green open space (RTHKP) as part of the open space of an urban area filled with plants and plants to support ecological, social, cultural, economic, and aesthetic benefits.

The problems of Green Open Space in Denpasar City consist of:

1. Rapid urban development, resulting in a lot of land use shifting from agricultural cultivation areas to residential areas;

2. Most of the private green open spaces in urban agriculture have been converted into built-up (commercial) land;

3. Most of the existing riverbanks are built-up areas;

4. The green line is still lacking, both in quantity and quality;

5. Public awareness as part of stakeholders does not understand and care about the importance of green open space;

6. RTH under the SUTT and SUTET networks has not yet been fully released so that its functions are still widely used for other than RTH;

7. Handling of green open space that has not been carried out optimally by involving the private sector and the community; 
8. The existence of an open parking area is not accompanied by reforestation/planting of protective trees so that it includes only open space criteria;

9. The existence of economic actors/PKL around the city park area disrupts existing plants or vegetation;

10. There has been no firm action from the authorities/related for violators or destroyers of existing green open space; and

11. Lack of socialization regarding green open space by the relevant agencies to the community, causing there are still many green open spaces that do not comply with applicable regulations.

Changes to the environment as a result of land-use change can lead to reduced water catchment areas in urban areas which results in dry land during the summer, but floods during the rainy season. The factor is the lack of supervision from the Denpasar City Government in the use and use of land, the weak handling and law enforcement against violations committed by community members, and the absence of strict sanctions resulting in no deterrent effect from the violators.

The transfer of the function of spatial use and the environment in Denpasar City is the cause of the difficulty in realizing the fulfillment of the area of green open space from a predetermined proportion. The area of the existing green open space is not following the target set in the Denpasar City RTRW and also has not been able to meet the provisions of Law Number 26 of 2007 concerning Spatial Planning which stipulates that the ideal area of green open space for urban areas (RTHKP) is at least $30 \%$ consisting of $20 \%$ public green open space and $10 \%$ private green open space of the area.

Identification analysis on the internal part of the use of public green open spaces and management strategies for public green open spaces in Denpasar produces an overview of internal factors that are the strengths and weaknesses of the utilization and management of public green open spaces in Denpasar. The results of the internal weighting and rating factors will be formulated in the form of an IFE matrix. The IFE matrix can summarize and evaluate the main strengths and weaknesses. The formulation of the IFE matrix for the use of public green open spaces in Denpasar can be seen in Table 3 .

Table 3 IFE Matrix of Denpasar City Public Green Open Space Utilization

\begin{tabular}{lllll}
\hline No & $\begin{array}{l}\text { Internal Factors } \\
\text { POWER }\end{array}$ & Weight & Rating & Score \\
\hline 1 & $\begin{array}{l}\text { There is community support/participation in } \\
\text { the Denpasar city area regarding the use of } \\
\text { public green open space }\end{array}$ & 0.14 & 3.73 & 0.52 \\
\hline & $\begin{array}{l}\text { The existence of assets belonging to the Den- } \\
\text { pasar city government that can be used as the } \\
\text { use of public green open space }\end{array}$ & & & \\
\hline
\end{tabular}

Continued on next page 


\begin{tabular}{|c|c|c|c|c|}
\hline \multicolumn{5}{|c|}{ Table 3 continued } \\
\hline 3 & $\begin{array}{l}\text { There is a cooperation between the local gov- } \\
\text { ernment and the local community in the use of } \\
\text { public green open space in the Denpasar city } \\
\text { area }\end{array}$ & 0.14 & 3.73 & 0.53 \\
\hline 4 & $\begin{array}{l}\text { There is a cooperation between the local gov- } \\
\text { ernment and the private sector/NGO regard- } \\
\text { ing the use of public green open space in the } \\
\text { Denpasar city area }\end{array}$ & 0.14 & 3.73 & 0.40 \\
\hline 5 & $\begin{array}{l}\text { There is policy support in the form of regu- } \\
\text { latory directives and incentives in the use of } \\
\text { public green open space in the Denpasar city } \\
\text { area }\end{array}$ & 0.12 & 3.27 & 0.53 \\
\hline 6 & $\begin{array}{l}\text { There is a method/concept development in } \\
\text { the use of public green open space in the Den- } \\
\text { pasar city area }\end{array}$ & 0.01 & 0.53 & 0.01 \\
\hline \multirow[t]{2}{*}{7} & $\begin{array}{l}\text { There are adequate funds for the use of new } \\
\text { public green open spaces in the Denpasar city } \\
\text { area }\end{array}$ & 0.02 & 0.27 & 0.00 \\
\hline & WEAKNESS & & & \\
\hline 1 & $\begin{array}{l}\text { Lack of local cultural social support in the use } \\
\text { of public green open space in the Denpasar } \\
\text { city area }\end{array}$ & 0.06 & 1.53 & 0.09 \\
\hline 2 & $\begin{array}{l}\text { Lack of stakeholder human resources related } \\
\text { to the use and management of public green } \\
\text { open space in the Denpasar city area }\end{array}$ & 0.04 & 1.13 & 0.05 \\
\hline 3 & $\begin{array}{l}\text { The availability of space in the Denpasar city } \\
\text { area is limited, so it cannot accommodate the } \\
\text { growth of urban built land }\end{array}$ & 0.04 & 1.13 & 0.05 \\
\hline 4 & $\begin{array}{l}\text { The number of private land ownership domi- } \\
\text { nates so that it is difficult for the government } \\
\text { to intervene in the use of public green open } \\
\text { space in the Denpasar city area. }\end{array}$ & 0.05 & 1.40 & 0.08 \\
\hline 5 & $\begin{array}{l}\text { There are no regional policy directives (incen- } \\
\text { tives - disincentives and spatial planning con- } \\
\text { cepts) that support the use of public green } \\
\text { open space in the Denpasar City Area. }\end{array}$ & 0.05 & 1.27 & 0.07 \\
\hline 6 & $\begin{array}{l}\text { The lack of supervision related to controlling } \\
\text { the use of space so that many irregularities in } \\
\text { land use should be designated as public green } \\
\text { open space areas or protected areas (green } \\
\text { lanes, river borders, coastal borders, catch- } \\
\text { ment areas and springs, ravine borders, SUTT, } \\
\text { etc.) in the city area Denpasar. }\end{array}$ & 0.02 & 0.07 & 0.00 \\
\hline 7 & $\begin{array}{l}\text { Lack of method/concept development in the } \\
\text { use of public green open space in the Denpasar } \\
\text { city area }\end{array}$ & 0.01 & 0.13 & 0.00 \\
\hline \multirow[t]{2}{*}{8} & $\begin{array}{l}\text { The requirement for fulfilling } 20 \% \text { public } \\
\text { green open space has not been achieved }\end{array}$ & 0.00 & 0.07 & 0.00 \\
\hline & Total & 1,00 & & 2,80 \\
\hline
\end{tabular}


The IFE matrix above shows the results of respondents' assessment of the use of Denpasar's public green open space in utilizing strengths and minimizing weaknesses has a total value of 2.80. There are 2 (two) greatest strengths of the Denpasar city public green open space utilization area which lies in the existence of policy support in the form of regulatory directions and incentives in the use of public green open space in the Denpasar city area with a value of 0.53 . Then the second strength is the existence of community support/participation in the Denpasar city area regarding the use of public green open space with a value of 0.52 . While the main weakness is seen from the value of the lowest score weight. There are 4 (four) main weaknesses, namely the requirement for fulfilling $20 \%$ public green open space with a value of 0.00 has not been achieved. Then for the second weakness, the availability of space in the Denpasar city area is limited, so it cannot accommodate the growth of urban built land with a value of 0.05 . Policy support in the form of regulatory directives and incentives in the use of public green open space in the Denpasar city area, and the support/participation of the public in the Denpasar city area regarding the use of public green open space.

Identification of the external factors of the use of public green open space in the city of Denpasar produces a picture of external factors in the form of opportunities and threats faced. The results of the weighting and provision of external factors will be formulated in the form of an EFE matrix. The EFE matrix can summarize as well as evaluate the main strengths and weaknesses of the use of Denpasar's public green open space. The formulation of the EFE matrix for the use of public green open spaces can be seen in Table 4 .

\section{Table 4 Results of external factor analysis}

\begin{tabular}{|c|c|c|c|c|}
\hline No & External Factors & Weight & Rating & Score \\
\hline & OPPORTUNITY & & & \\
\hline 1 & $\begin{array}{l}\text { The existence of state assets belonging to the province } \\
\text { and the center that can be used as public green open } \\
\text { space in the Denpasar city area }\end{array}$ & 0.13 & 3.10 & 0.37 \\
\hline 2 & $\begin{array}{l}\text { The existence of communities or institutions (gov- } \\
\text { ernment agencies, private sector, NGOs) from outside } \\
\text { the Denpasar City area who support the use of public } \\
\text { green open space. }\end{array}$ & 0.05 & 3.20 & 0.14 \\
\hline 3 & $\begin{array}{l}\text { There are policy directions for Bali Province, National, } \\
\text { and International Issues that support the use of public } \\
\text { green open space in the Denpasar City area. }\end{array}$ & 0.15 & 3.80 & 0.58 \\
\hline 4 & $\begin{array}{l}\text { The use of modern technology in supporting the use } \\
\text { of public green open space in the Denpasar city area. }\end{array}$ & 0.14 & 3.40 & 0.40 \\
\hline 5 & $\begin{array}{l}\text { There is special funding from the private sector, NGOs, } \\
\text { Bali Province, National, and International regarding } \\
\text { the use of public green open space in the Denpasar city } \\
\text { area }\end{array}$ & 0.14 & 3.40 & 0.40 \\
\hline 6 & $\begin{array}{l}\text { Increased public awareness and attention to healthy, } \\
\text { safe, and comfortable environmental conditions }\end{array}$ & 0.10 & 0.50 & 0.50 \\
\hline
\end{tabular}




\begin{tabular}{|c|c|c|c|c|}
\hline \multicolumn{5}{|c|}{ Table 4 continued } \\
\hline 7 & $\begin{array}{l}\text { Assistance with the availability of clean water facilities } \\
\text { at public green open spaces }\end{array}$ & 0.01 & 0.10 & 0.00 \\
\hline & THREATS & & & \\
\hline 1 & $\begin{array}{l}\text { The existence of central and national interests that } \\
\text { threaten the lack of use of public green open space in } \\
\text { the Denpasar city area }\end{array}$ & 0.07 & 1.73 & 0.10 \\
\hline 2 & $\begin{array}{l}\text { The increasing number of residents due to migration } \\
\text { from outside to the Denpasar city area has resulted in } \\
\text { the conversion of land functions to built-up land in the } \\
\text { Denpasar city area }\end{array}$ & 0.05 & 1.53 & 0.07 \\
\hline 3 & $\begin{array}{l}\text { There are capital parties (investors) from those who } \\
\text { build/use land on land that should be designated as } \\
\text { green open space or protected areas (green lines, } \\
\text { river borders, coastal borders, catchment areas, and } \\
\text { springs, etc.). }\end{array}$ & 0.05 & 1.27 & 0.07 \\
\hline 4 & $\begin{array}{l}\text { There are policy directions that contradict the use of } \\
\text { public green open space in the Denpasar city area. }\end{array}$ & & & \\
\hline 5 & $\begin{array}{l}\text { There is a threat related to the use of public green open } \\
\text { space in the Denpasar city area due to the develop- } \\
\text { ment of modern technology. }\end{array}$ & 0.00 & 0.07 & 0.00 \\
\hline 6 & $\begin{array}{l}\text { There are more priority expenditures so that funding } \\
\text { cannot be allocated for the use of public green open } \\
\text { space in the Denpasar city area. }\end{array}$ & 0.00 & 1.47 & 0.07 \\
\hline 7 & $\begin{array}{l}\text { The growing activity causes the need for land and } \\
\text { facilities to increase }\end{array}$ & 0.00 & 0.07 & 0.00 \\
\hline 8 & $\begin{array}{l}\text { The impact of land conversion on people's lives, espe- } \\
\text { cially the city of Denpasar, such as poor oxygen qual- } \\
\text { ity, reduced water catchment areas, causing flooding, } \\
\text { hotter temperatures, uncontrolled rainfall, etc. }\end{array}$ & 0.050 .06 & $\begin{array}{l}1.47 \\
0.07\end{array}$ & 0.070 .06 \\
\hline & Total & 1.00 & & 2.83 \\
\hline
\end{tabular}

The EFE matrix of the utilization of Denpasar's public green open space above shows the results of respondents' assessment of the use of Denpasar's public green open space has a total value of 2.83. Utilization of public green open space Denpasar city has a high enough ability to take advantage of existing opportunities and overcome threats that come. The greatest opportunity for the utilization of Denpasar's public green open space lies in the direction of the Bali Provincial, National, and International Issues policies that support the use of public green open space in the Denpasar City Area with a value of 0.58 . The second biggest opportunity is increasing public awareness and attention to healthy, safe, and comfortable environmental conditions with a value of 0.52 . Meanwhile, the 2 (two) biggest threats that come to the use of public green open space in Denpasar are the existence of policy directions that contradict the use of public green open space in the Denpasar city area with a value of 0.00 Then for the second biggest threat, namely the impact of land conversion on people's lives such as poor oxygen quality, reduced water catchment areas causing flooding, hotter temperatures, uncontrolled rainfall, with a value of 0.06 . 
Based on the internal-external matrix (IE) which serves to determine the position of the use of public green open space in Denpasar city according to the IFE matrix formulation owned by the Denpasar city public green open space utilization area, the total value is 2.80 which indicates that the public green open space utilization area is Denpasar city has an average ability to take advantage of strengths and minimize weaknesses. While in the EFE Matrix, the Denpasar city public green open space utilization area has a total value of 2.83, it can be concluded that the opportunity for the Denpasar city public green open space utilization area can be utilized to cover existing threats. If the two values are brought together, they will be in cell V of the IE matrix, namely the maintain and maintain column (the strategy does not change).

Based on these conditions, the strategy undertaken to utilize public green open space in the city of Denpasar is to intensify the socialization and supervision of the Denpasar RTRW regional regulation and encourage the preparation of a detailed spatial plan for the city of Denpasar. The following are some strategies for controlling the use of space in the public green open space utilization area of Denpasar:

1. Installing an information board on the Denpasar City RTRW map in the public green open space utilization area of Denpasar city to increase public understanding of the importance of the Denpasar city public green open space utilization area which functions as protection, aesthetics, comfort, security, and sustainability.

2. Develop a detailed spatial plan (spatial detail plan) so that it will become a regional regulation as the basis for spatial utilization rules.

3. Implementing incentive and disincentive programs to relevant stakeholders to control space utilization.

4. Strengthening the enforcement of local regulations on the Denpasar City Spatial Plan.

The formulation of priority strategies for controlling the use of space using the Analytical Hierarchy Process (AHP) is an alternative strategy for controlling the use of public green open spaces:

1. Installing an information board for the Denpasar City Spatial Planning (RTRW) map (alternative 1). This strategy aims to increase public understanding of the importance of using public green open space in the city of Denpasar which functions to protect and as an effort to preserve, maintain and protect.

2. Develop a detailed spatial plan (RDTR) until it is passed into a regional regulation (alternative 2). This strategy aims as a guideline/basis for the Denpasar city government in granting space utilization permits.

3. Implementing incentive and disincentive programs to relevant stakeholders (alternative 3). This strategy aims to make the Denpasar city government provide incentives for the use of space that is following the spatial plan and disincentives for those who violate the use of space that is not by the spatial plan. 
4. Strengthening the enforcement of the Denpasar RTRW local regulation (alternative 4). This strategy aims to monitor the use of space through the imposition of sanctions for violations of spatial planning. The results of the AHP analysis are presented in Table 5 .

\begin{tabular}{llc}
\hline Table 5 Results of Analytical Hierarchy Process (AHP) & \\
\hline Priority & $\begin{array}{l}\text { Suitability of Utilization of Public Green Open Space } \\
\text { Develop a detailed spatial plan (RDTR) until it is ratified into a } \\
\text { regional regulation }\end{array}$ & Weight \\
\hline 2 & $\begin{array}{l}\text { Installing the Denpasar City RTRW map information board } \\
\text { Strengthening in enforcing the law of the Denpasar City RTRW }\end{array}$ & 0.317 \\
\hline 3 & $\begin{array}{l}\text { Regulation } \\
\text { Implementing incentive and disincentive programs to relevant } \\
\text { stakeholders }\end{array}$ & 0.294 \\
\hline
\end{tabular}

\section{CONCLUSIONS}

1. The availability of public green open space in 2011 was recorded at $2,341.48$ or 18.32 percent, decreasing in 2019 to $1,572,990$ ha or 12.49 percent. There has been a decrease in the public green open space area from time to time, so it does not meet the $20 \%$ requirement of the Denpasar city area.

2. The strategy for managing public green open spaces in the city of Denpasar should be carried out by preparing a detailed spatial plan (RDTR) until it is ratified into a regional regulation, installing an information board on the RTRW map, strengthening the law in enforcing the RTRW regional regulation, and implementing incentive and disincentive programs for residents. related stakeholders

\section{ACKNOWLEDGEMENTS}

Acknowledgments are conveyed to the Director of Postgraduate and Head of Study Programs of the Masters of Regional Planning and Environmental Management, Mahasaraswati University Denpasar, the supervisors and reviewers who helped and motivated the completion of the research carried out.

\section{GOVERNMENT REGULATION OF THE REPUBLIC OF INDONESIA}

Law of the Republic of Indonesia Number 26 of 2007 concerning Spatial Planning

Law Number 05 of 1960 concerning Basic Regulations on Agrarian Principles.

Director General. (2008). Regulation of the Minister of Public Works Number: 05/PRT/M/2008 concerning Guidelines for Provision and Utilization of Green Open Spaces in Urban Areas. Public Works Department. 
Regulation of the Minister of Public Works Number: 05/PRT/M/2008 concerning Guidelines for Provision and Utilization of Green Open Spaces in Urban Areas

Ministerial Regulation Number 1 of 2007 concerning Functions and Benefits of Urban Green Open Space Management.

Provincial Regulation of Bali Number 16 of 2009 concerning Spatial Planning of the Province of Bali in 2009-2029.

Denpasar City Regional Regulation Number 27 of 2011 concerning Spatial Planning for the City of Denpasar of 2011-2031

Denpasar City Regional Regulation Number 5 of 2016 concerning the Mid-Term Development Plan for the Badung Regency of 2016-2021

Denpasar City Regional Regulation Number 1 of 2009 concerning the Long-Term Development Plan of the Badung Regency for the Year 2005-2025.

\section{REFERENCES}

Alfiah, C. (2008). Study of the Functions of City Green Open Space in Various Space Clusters in the City of Yogyakarta (Unpublished doctoral dissertation). Graduate School of Environmental Science Study Program, Gadjah Mada University, Yogyakarta (in Bahasa).

As-Syakur, A. R. (2011). Analysis of Vegetation Index Using ALOS AVNIR-2 Imagery and Geographic Information System (GIS) for Spatial Evaluation of Denpasar City. Bumi Lestari Journal, 9, 1-11.

Bettinger, P., Boston, K., Siry, J. P., \& Grebner, D. L. (2009). Forest Management and Planning. Oxford, UK: Elsevier.

Chili. (2004 a). Is the Grass Greener? Learning from International Innovation in Urban Green Space Management. . London: Commission for Architecture and the Built Environment.

Chili. (2004 b). Manifesto for Better Public Space. . London: Commission for Architecture and the Built Environment: CABE Publication.

Chili. (2004 c). Parks Need People - the Skills Shortage in Parks: A Summary of Research. London: Commission for Architecture and the Built Environment, CABE Publication.

CHILI. (2005). A Guide to producing Park and Green Space Management Plans. London: Commission for Architecture and the Built Environment. CABE Publication.

City, D. (2017). Statistics Center in Figures for 2017.

David, F. R. (2017). Strategic Management Concepts and Cases. England: Pearson.

Rangkuti, F. (2000). SWOT Analysis Techniques to Dissect Business Cases. Jakarta: PT. Main Library Gramedia.

Reklaitiene, R., Grazuleviciene, R., Dedele, A., Virviciute, D., Vensloviene, J., Tamosiunas, A., Baceviciene, M., Luksiene, D., Sapranaviciute-Zabazlajeva, L., Radisauskas, R., Bernotiene, G., Bobak, M., \& Nieuwenhuijsen, M. J. (2014). The relationship of green space, depressive symptoms and perceived general health in urban population. Scandinavian Journal of Public Health, 42(7), 669-676. Retrieved from https://dx.doi.org/ $10.1177 / 140349481454449410.1177 / 1403494814544494$

Sugiyono. (2011). Quantitative, Qualitative, and R\&D Research Methods. Bandung: Alphabeta. (in Bahasa) . 